Матвійчук B.I.,

к.е.н., доцент, ДонНУ імені Василя Стуса

ORCID ID 0000-0002-1032-3060

v.matviichuk@donnu.edu.ua

Золотар А.К., ДонНУ імені Василя Стуса

ORCID ID 0000-0002-7421-0807

zolotar.a@donnu.edu.ua

\title{
ПРАКТИЧНЕ ВИКОРИСТАННЯ МЕТОДІВ МІНІМІЗАЦІЇ КРЕДИТНОГО РИЗИКУ НА ПРИКЛАДІ ПАТ АБ «УКРГАЗБАНК»
}

Досліджено теоретичні аспекти оичнки кредитного ризику. 3'ясовано економікоправові засади управління кредитними ризиками банку. Запропоновано модель оцінки ризику кредитного портфеля банку, що базується на використанні інтегрального показника, та розраховано його значення для ПАТ АБ «Укргазбанк». Проаналізовано ступінь впливу кожного фактору на значення інтегрального коефіцієнту оцінки кредитного ризику. Запропоновано заходи банківського менеджменту для покращення результатів управління кредитними ризиками.

Ключові слова: кредитний ризик, методи управління, інтегральний показник, модель очінки ризику кредитного портфелю банку.

Рис. -1 , Табл. -4 , Літ. -8

Постановка проблеми. Банківське кредитування залишається джерелом формування фінансових ресурсів суб'єктів економічної діяльності, не зважаючи на загострення кризових ситуацій в реальному секторі економіки України. Тому кредитні ризики в структурі фінансових ризиків банків мають визначальний вплив на результати їх діяльності.

Кредитний ризик - це можливе настання неплатоспроможності позичальника, за рахунок чого він не в змозі сплатити основну суму боргу та відсотків протягом терміну користування кредитом, який визначений договором. Розширення кредитування підприємств і організацій з невисоким рівнем кредитоспроможності, а також висока концентрація кредитних ризиків в слабких галузях і окремих підприємствах, обумовлює тенденцію зростання реального рівня кредитного ризику банків в Україні.

Для більшості українських банків головною ціллю $є$ мінімізація рівня кредитного ризику, забезпечуючи стабільне функціонування на ринку. Проблема пошуку нових підходів до управління кредитним ризиком банків $є$ досить актуальною і повинна розглядатися як головний елемент формування нової парадигми кредитної політики. Перш за все, необхідна систематизація банками існуючих методів мінімізації кредитних ризиків, оскільки це дає змогу не лише запобігти можливим втратам банку від кредитної діяльності, а й не допустити виникнення серйозних проблем із 
ліквідністю та платоспроможністю банківського бізнесу. I по-друге, банкам потрібно активізувати процеси створення та реалізації нових, спеціалізованих методів уникнення або мінімізації кредитних ризиків банківської структури.

Аналіз останніх досліджень і публікацій. Теоретичні та методичні рекомендації щодо вирішення окремих аспектів мінімізації кредитних ризиків банків були висвітлені в роботах В. Волкової, Д. Гладких, В. Грушка, Т. Іваненка, Н. Жукова, Н. Зражевської, I. Бєлова, О. Стешенка, О. Терещенка [1-5] та інших. Але, незважаючи на існуючі теоретичні та практичні розробки, дослідження цієї проблеми потребує подальшого вивчення. Актуальним є розробка методів мінімізації кредитного ризику, використання яких буде сприяти активізації кредитної політики банківської системи за рахунок стабільної роботи та максимального зменшення обсягів кредитування неплатоспроможних підприємств.

Мета роботи полягає у вдосконалення методів оцінки кредитного ризику банку, завдяки вирішенню комплексу теоретичних i практичних проблем управління кредитними ризиками та апробація їх на ПАТ АБ «Укргазбанк».

Результати дослідження. Пріоритетними напрямками діяльності сучасних українських банків $є$ кредитні операції, тому що вони є основою формування прибутку банківської установи. В Законі України «Про банки і банківську діяльність» банківський кредит трактується як зобов'язання банку надати певну суму грошей ...» [6, ст. 2]. Для банків кредитні операції є першочерговим джерелом прибутку, а для позичальників - можливість отримати необхідні фінансові ресурси.

За визначенням НБУ, кредитний ризик визначається як «...наявний або потенційний ризик для надходжень і капіталу, який виникає через неспроможність сторони, що взяла на себе зобов'язання, виконати умови будь-якої фінансової угоди із банком або в інший спосіб виконати взяті на себе зобов'язання» [7].

Нестабільне фінансово-економічне середовище на фінансових ринках та ринках банківських послуг, зниження платоспроможності позичальників, неправильно сформовані стратегії банків - це постійні загрози нормальному функціонуванню банківських установ, що зумовлюють поступову втрату ними своєї фінансової стійкості. Банки намагаються мінімізувати свої ризики, це необхідно для скорочення втрат і подальшого розвитку фінансової установи. Мінімізація ризиків враховує наступні складові 3 передбачення ризиків та втрат, до яких може призвести ризик: розміри капіталу, наслідки для банківської установи, а також заходів щодо запобігання та мінімізації або усунення збитків.

Необхідність дотримання правил, вимог і нормативів НБУ щодо кредитних ризиків є основою повноцінної, безперебійної та ефективної роботи комерційного банку. Наявність негативних відхилень від встановлених нормативів створюють загрозу не тільки для банку, але і для клієнтів та стійкості банківської системи у цілому. Тому відповідність нормативам кредитного ризику $\epsilon$ першим етапом комплексної оцінки кредитного ризику банку.

Досить поширеною проблемою в українській банківській системі є значний обсяг непрацюючих кредитів (рис.1), який безпосередньо впливає на рівень кредитного ризику - результат кредитної експансії минулих років, коли стандарти оцінювання платоспроможності позичальників були низькими, а права кредиторів недостатньо захищеними. Велика їх частка - тягар для банківського сектору, особливо для державних банків. НБУ наголошує, що банки мають інтенсивніше розчищати баланси: непрацюючі кредити слід реструктурувати, продати чи списати [8]. 


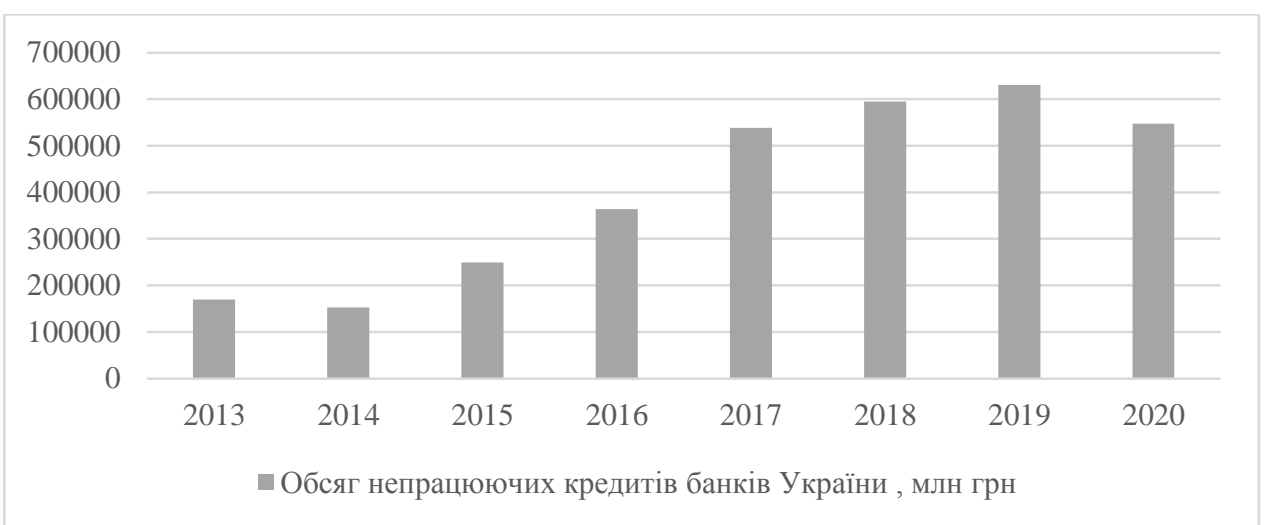

Рисунок 1. Динаміка обсягу непрацюючих кредитів банків України 2013-2020 pp.

Серед різноманіття форм і методів оцінки кредитного ризику одним з найбільш ефективних $\epsilon$ коефіцієнтний метод, суть якого полягає в розрахунку сукупності відносних показників, які відображають ступінь якості і ефективності управління. Оцінка якості та ефективності кредитної політики є одним із першочергових завдань управління банку. Своєчасно виявляючи слабкі місця i загрози, банк прагне максимізувати фінансовий ефект від кредитного портфеля та оптимізувати рівень ризику. Для оцінки рівня кредитного ризику доцільно використовувати інтегральний показник. Існують певні різновиди розрахунку інтегрального показника, кожен з яких має свої переваги і недоліки (табл. 1). Перевагою застосування інтегрального показника для оцінки кредитного ризику над іншими методами $\epsilon$ те, що в основі його розрахунку лежить об'єднання та систематизація окремих параметрів кредитної діяльності банку, оцінка ефективності управління кредитного ризику.

Таблиця 1

Різновиди методів побудови інтегрального показника, їх переваги і недоліки

\begin{tabular}{|c|c|c|}
\hline Методи побудови & Опис методу & Переваги і недоліки \\
\hline $\begin{array}{l}\text { 1. За сумою } \\
\text { показників }\end{array}$ & $\begin{array}{c}K=\sum_{j=1}^{n} K_{i} \\
\text { де } K_{i}-\text { окремі показники оцінки }\end{array}$ & $\begin{array}{l}\text { Перевага: простота у застосуванні. } \\
\text { Недолік: окремі показники не завжди грають } \\
\text { однаково важливу роль в загальному } \\
\text { дослідженні. }\end{array}$ \\
\hline $\begin{array}{c}\text { 2. За сумою } \\
\text { середньозважених } \\
\text { арифметичних } \\
\text { групових } \\
\text { показників }\end{array}$ & $\begin{array}{c}K=\sum_{i=1} W_{i} K_{i} \\
\text { де } K_{i} \text { - одиничні показники } \\
\text { оцінки з загальним числом } \mathrm{N} ; \\
W_{i} \text { - показник значимості (ваги) } \\
\text { і-го одиничного показника }\end{array}$ & $\begin{array}{l}\text { Перевага: інтегральний показник більш точно } \\
\text { відображає ефективність і результати } \\
\text { діяльності банку за рахунок використання } \\
\text { великої кількості коефіцієнтів. } \\
\text { Недолік: експертна оцінка може значно } \\
\text { змінити значення інтегрального показника } \\
\begin{array}{l}\text { через специфіку розрахунку результатів } \\
\text { опитування }\end{array}\end{array}$ \\
\hline $\begin{array}{c}\text { 3. За добутку } \\
\text { середньозважених } \\
\text { геометричних } \\
\text { групових } \\
\text { показників }\end{array}$ & $\begin{array}{c}K=\prod_{i=1}^{N} K_{i}^{W_{i}}, \\
\text { де } K_{i} \text { - одиничні показники } \\
\text { оцінки з загальним числом } \\
\mathrm{N} ; W_{i} \text { - вагомість одиничних } \\
\text { показників оцінки; } \Pi \text {-аргументи } \\
\text { з номерами } \mathrm{i}=1,2,3, \ldots \\
\end{array}$ & 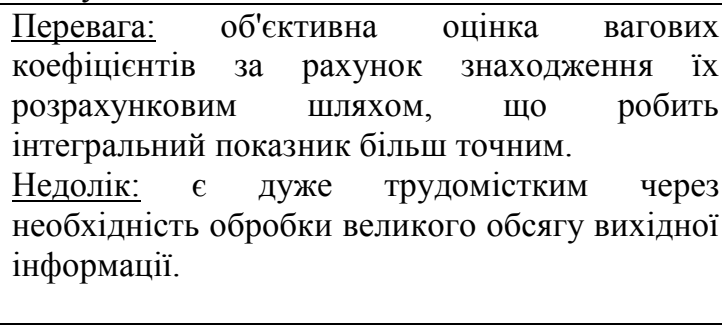 \\
\hline
\end{tabular}

На основі вивчення усіх підходів щодо формування інтегрального показника, їх переваг і недоліків, визначено оптимальний варіант побудови інтегрального показника оцінки кредитного ризику - розрахунок значення показника за сумою 
середньозважених арифметичних групових показників. Даний показник включає в себе максимальну кількість факторів впливу на кредитний ризик та за результатами дослідження усіх факторів, дає найбільш точний результат розрахунку. Запропонований інтегральний показник оцінює три ключові напрямки: ефективність формування кредитного портфелю, його якість та дотримання нормативів НБУ щодо кредитних ризиків банку.

Причинами зростання рівня кредитного ризику, дестабілізації банку, виникнення проблем у процесі поточної діяльності слід визначити неякісно сформований кредитний портфель, недотримання загальних принципів надання та обслуговування кредитів, недотримання нормативів НБУ щодо кредитного ризику. Тому обов'язковою складовою оцінки кредитного ризику за допомогою інтегрального показника $\epsilon$ використання коефіцієнтів, які будуть відображати рівень відповідності нормативам кредитного ризику, якості та ефективності формування кредитного портфеля. Характеристика показників, розрахункові та нормативні значення представлено в табл. 2.

Таблиця 2

Система коефіцієнтів для розрахунку інтегрального показника

\begin{tabular}{|c|c|c|c|}
\hline Коефіцієнти & Зміст & Формула розрахунку & $\begin{array}{c}\text { Нормативне } \\
\text { значення }\end{array}$ \\
\hline 1 & 2 & 3 & 4 \\
\hline \multicolumn{4}{|c|}{ Обов’язкові нормативи НБУ } \\
\hline $\mathrm{X}_{1}$ & $\begin{array}{c}\text { Норматив максимального } \\
\text { розміру кредитного ризику } \\
\text { на одного контрагента } \\
\text { (H7) }\end{array}$ & $\begin{array}{c}\text { Сума вимог банку до контрагента та всіх } \\
\text { позабалансових зобов’язань, виданих } \\
\text { банком щодо контрагента / Регулятивний } \\
\text { капітал банку } \\
\end{array}$ & $<0,25$ \\
\hline $\mathrm{X}_{2}$ & $\begin{array}{c}\text { Норматив великих } \\
\text { кредитних ризиків (H8) }\end{array}$ & $\begin{array}{c}\text { Сума всіх великих кредитних ризиків, } \\
\text { наданих банком щодо всіх контрагентів, } 3 \\
\text { врахуванням всіх позабалансових } \\
\text { зобов’язань, виданих банком щодо цих } \\
\text { контрагентів / Регулятивний капітал банку }\end{array}$ & $<8$ \\
\hline $\mathrm{X}_{3}$ & $\begin{array}{c}\text { Норматив максимального } \\
\text { розміру кредитів, гарантій, } \\
\text { наданих одному інсайдеру } \\
\text { (Н9) }\end{array}$ & $\begin{array}{c}\text { Сума всіх зобов’язань інсайдера (групи } \\
\text { пов'язаних інсайдерів) перед банком і всіх } \\
\text { позабалансових зобов'язань, виданих } \\
\text { банком щодо цього інсайдера / Статутний } \\
\text { капітал банку }\end{array}$ & $<0,25$ \\
\hline \multicolumn{4}{|c|}{ Оцінка ризику втрати якості кредитного портфелю } \\
\hline $\mathrm{X}_{4}$ & $\begin{array}{c}\text { Коефіцієнт збитковості } \\
\text { виданих кредитів }\end{array}$ & $\begin{array}{c}\text { Витрати на кредитні збитки / Кредити } \\
\text { клієнтам }\end{array}$ & $<0,03$ \\
\hline $\mathrm{X}_{5}$ & $\begin{array}{c}\text { Частка проблемних } \\
\text { кредитів }\end{array}$ & $\begin{array}{c}\text { Списані проблемні кредити / Кредити } \\
\text { клієнтам }\end{array}$ & $<0,03$ \\
\hline $\mathrm{X}_{6}$ & $\begin{array}{c}\text { Частка незабезпечених } \\
\text { кредитів }\end{array}$ & $\begin{array}{c}\text { Кредити без забезпечення / Кредити } \\
\text { клієнтам }\end{array}$ & $<0,5$ \\
\hline $\mathrm{X}_{7}$ & $\begin{array}{c}\text { Коефіцієнт валютних втрат } \\
\text { по кредитам }\end{array}$ & $\begin{array}{c}\text { Валютні втрати по кредитуванню / } \\
\text { Кредити клієнтам }\end{array}$ & $<0,03$ \\
\hline \multicolumn{4}{|c|}{ Показники оцінки ризику втрати прибутковості кредитного портфелю } \\
\hline $\mathrm{X}_{8}$ & $\begin{array}{c}\text { Показник співвідношення } \\
\text { процентних прибутків і } \\
\text { процентних витрат } \\
\end{array}$ & Процентні доходи/ Процентні витрати & $>1$ \\
\hline $\mathrm{X}_{9}$ & $\begin{array}{c}\text { Чиста маржа процентного } \\
\text { прибутку }\end{array}$ & $\begin{array}{c}\text { (Процентні доходи - Процентні витрати) / } \\
\text { Кредити клієнтам }\end{array}$ & $>0,03$ \\
\hline $\mathrm{X}_{10}$ & $\begin{array}{c}\text { Рентабельність кредитного } \\
\text { портфелю }\end{array}$ & Чистий прибуток / Кредити клієнтам & $>0$ \\
\hline
\end{tabular}


Вага кожного коефіцієнта визначається ступенем його впливу на сукупний кредитний ризик. Виявити ступінь впливу показника та його важливість серед сукупності інших індикаторів за допомогою аналізу статистичних даних практично неможливо, оскільки має місце вплив багатьох факторів, як відомих, так i невизначених, тобто для аналізу бракує інформації. Тому за допомогою встановлених нормативів для кожного коефіцієнта, розроблено градацію рівня кредитного ризику (табл. 3), виходячи із оптимальних, нормальних та кризових значень коефіцієнтів.

Таблиця 3

Градація рівня кредитного ризику банку

\begin{tabular}{|c|c|}
\hline Значення коефіцієнтів & Оцінка рівня кредитного ризику \\
\hline $\mathrm{ABCR}<1,253$ & Низький ризик \\
\hline $1,253<\mathrm{ABCR}<1,616$ & Значний рівень ризику \\
\hline $1,616<\mathrm{ABCR}<1,885$ & Високий рівень кредитного ризику \\
\hline $\mathrm{ABCR}>1,885$ & Кризовий рівень кредитного ризику \\
\hline
\end{tabular}

Джерело: складено автором

Заключним етапом розробки інтегрального показника оцінки кредитного ризику банку є безпосередня апробація даної моделі для ПАТ АБ «Укргазбанк», результати представлені в таблиці 4. Необхідно відзначити, що в процесі розрахунку інтегрального показника необхідно враховувати нормативні значення коефіцієнтів кредитного ризику 3 метою виявлення особливостей змін і виявлення факторів впливу на підсумкове значення інтегрального показника. Крім того, доцільно проводити розрахунок за кілька періодів з метою визначення динаміки показників.

Таблиця 4

Оцінка кредитного ризику ПАТ АБ «Укргазбанк» за допомогою інтегрального показника

\begin{tabular}{|c|c|c|c|c|c|c|}
\hline \multirow{2}{*}{ Коефіціснт } & \multirow{2}{*}{ Норматив } & \multirow{2}{*}{$\mathbf{2 0 1 7}$} & \multirow{2}{*}{$\mathbf{2 0 1 8}$} & \multirow{2}{*}{$\mathbf{2 0 1 9}$} & \multicolumn{2}{|c|}{ Темп росту, \% } \\
\cline { 6 - 7 } & & & & & $2018 / 2017$ & $2019 / 2018$ \\
\hline $\mathrm{X}_{1}$ & $<0,25$ & 0,003 & 0,156 & 0,197 & 4465,7 & 125,8 \\
\hline $\mathrm{X}_{2}$ & $<8$ & 3,803 & 2,246 & 4,597 & 59,1 & 204,7 \\
\hline $\mathrm{X}_{3}$ & $<0,25$ & 4,370 & 10,050 & 0,320 & 230,0 & 3,2 \\
\hline $\mathrm{X}_{4}$ & $<0,03$ & 0,012 & 0,010 & 0,013 & 87,9 & 128,5 \\
\hline $\mathrm{X}_{5}$ & $<0,03$ & 0,033 & 0,026 & 0,032 & 80,8 & 119,9 \\
\hline $\mathrm{X}_{6}$ & $<0,5$ & 0,254 & 0,249 & 0,247 & 98,1 & 99,2 \\
\hline $\mathrm{X}_{7}$ & $<0,03$ & 0,051 & 0,013 & 0,079 & 25,2 & 613,7 \\
\hline $\mathrm{X}_{8}$ & $>1$ & 0,918 & 1,001 & 0,843 & 109,1 & 84,2 \\
\hline $\mathrm{X}_{9}$ & $>0,03$ & $-0,009$ & 0,0002 & $-0,023$ & $-1,9$ & $-13856,6$ \\
\hline $\mathrm{X}_{10}$ & $>0$ & 0,015 & 0,014 & 0,028 & 96,0 & 194,7 \\
\hline \multicolumn{2}{|c|}{ ABCR } & 0,94 & 1,38 & 0,63 & 145,7 & 46,0 \\
\hline
\end{tabular}

Джерело: складено автором

Отримані результати характеризують неоднозначну тенденцію: у 2018 році темп зростання розрахованого значення інтегрального показника складає $145,7 \%$, що показує значний рівень ризику. Зростання показника у 2018 році пов'язано із збільшенням фактичної величини обов'язкових нормативів. В 2019 році рівень кредитного ризику 
знижується в динаміці на $46 \%$, це свідчить про позитивну тенденцію зниження ризику для банку, за рахунок активізація інвестиційної діяльності та скорочення обсягу кредитування.

Менеджерам доцільно опрацювати ті напрямки, які призводять до негативних відхилень значень коефіцієнтів від нормативів, що $\epsilon$ складовими інтегрального показника, а саме:

1) дотримання значень обов'язкових нормативів в результаті переходу на більш консервативний варіант надання кредитів, який передбачає зниження кількості ризикованих кредитів (особливо надання довгострокових кредитів державним підприємствам);

2) активно скорочувати обсяг непрацюючих кредитів - навіть враховуючи той факт, що банк скорочує обсяг проблемних кредитів (в 2019 році - зменшення на 3,35\%), їх частка в кредитному портфелі залишається значною $(16,9 \%$ до кінця 2019 року). Тому рекомендується застосовувати часткове переведення кредитів до непрацюючих для стабілізації структури кредитного портфелю та зниження загального кредитного ризику;

3) зважаючи на те, що процентні витрати досить часто перевищують обсяг процентних доходів, потрібно переглянути процес формування процентної ставки по кредитах.

Поліпшення системи якості виявлення, мінімізації та управління кредитними ризиками дає основу для підвищення ефективності банківської діяльності та конкурентоспроможності банків.

Висновки. Таким чином, враховуючи особливості розвитку банківської системи України, необхідно відзначити, що кредитування залишається основною операцією для банків, тому кредитний ризик $є$ домінуючим серед інших банківських ризиків. Результати оцінки його рівня впливають на процес формування розміру капіталу, ліквідності банку, характеризуючи загрозу для інтересів вкладників. Дослідження методів мінімізації та управління кредитними ризиками $є$ ключовим та потребує постійної уваги в системі управління ризиками банківської структури.

Необхідним завданням для системи управління банку є впровадження моделі оцінювання кредитного ризику на основі визначення інтегрального показника кредитного ризику. Використання результатів розрахунку інтегрального показника для ПАТ АБ «Укргазбанк», дозволяє сформувати комплексні підходи щодо поліпшення якості політики управління кредитним ризиком та ефективності сформованого кредитного портфеля. Перевагою застосування інтегрального методу $є$ те, що в основі розрахунку його $є$ об'єднання та систематизація окремих параметрів кредитної діяльності банку, оцінка ефективності управління кредитного ризику.

Успішне практичне впровадження запропонованих управлінських заходів для зниження рівня кредитного ризику сприятиме надійному функціонуванню, фінансовій стійкості не тільки комерційного банку, але й банківської системи України.

\section{СПИСОК ВИКОРИСТАНИХ ДЖЕРЕЛ}

1. Волкова В.В. Методичнні аспекти управління ризиком кредитного портфеля банку. Економіка і організація управління. 2016. № 1(21). С. 45-52.

2. $\quad$ Гладких Д. Ризики і загрози банківській безпеці України за підсумками 2014 року. Вісник Національного банку України. 2015. № 4.С. 14-23.

3. Грушко В. Оптимізація структури кредитного портфеля комерційного банку. Вісник Національного банку України. 2014.№ 2.С.28-32. 
4. Жукова Н.К. Проблеми управління кредитним портфелем комерційних банків.Економічний часопис. 2013. №1. С.70-72.

5. Бєлова І.В. Впровадження нових вимог щодо оцінки кредитного ризику у банках України URL: http://www.inter-nauka.com\ (дата звернення: 20.10.2020)

6. Про банки і банківську діяльність: Закон України від 7 грудня 2000 р., №2121.111; №661-VI (661-17) від 12.12.2008 р. 2009. №15. С. 190.

7. Національний банк України. URL: https://old.bank.gov.ua/control/uk/publish/article?art_id=123415 (дата звернення: 03.11.2020)

8. Національний банк України. URL: https://bank.gov.ua/ua/stability/npl?fbclid=IwAR1M8WGMHHK14Cnzl46b3eDyJAojMIFW 8qoYZWj6ANKKZms_DHnV8DXqA (дата звернення: 06.11.2020)

Матвийчук В.И., к.э.н., доцент, ДонНУ имени Васыля Стуса, ORCID: 0000-0002-1032-3060 v.matviichuk@donnu.edu.ua

Золотарь А.К., ДонНУ имени Васыля Стуса

zolotar.a@donnu.edu.ua

ПРАКТИЧЕСКОЕ ИСПОЛЬЗОВАНИЕ МЕТОДОВ МИНИМИЗАЦИИ КРЕДИТНЫХ РИСКОВ НА ПРИМЕРЕ ПАО АБ «УКРГАЗБАНК»

Исследованы теоретические аспекты оченки кредитного риска. Выяснено экономико-правовые основы управления кредитными рисками банка. Предложена модель оценки риска кредитного портфеля банка, основана на использовании интегрального показателя и рассчитано эго значение для ПАО АБ «Укргазбанк». Проанализирована степень влияния каждого фактора на значение интегрального коэффициента оценки кредитного риска. Разработаны методы банковского менеджмента для улучшения результата управления кредитными рисками.

Ключевые слова: кредитный риск, методы управления, интегральный показатель, модель оценки риска кредитного портфеля банка.

V. Matviychuk, Candidate of Economic Sciences, Associate Professor, Vasyl' Stus Donetsk National University, ORCID: 0000-0002-1032-3060

v.matviichuk@donnu.edu.ua

A. Zolotar, Vasyl' Stus Donetsk National University

zolotar.a@donnu.edu.ua

PRACTICAL USE OF CREDIT RISK MINIMIZATION METHODS ON THE EXAMPLE OF PJSC JSB «UKRGASBANK»

Theoretical aspects of credit risk assessment are studied. The economic and legal bases of credit risk management of the bank are clarified. The model of risk assessment of the bank's loan portfolio based on the use of the integrated indicator is proposed and its value for PJSC JSB "Ukrgasbank" is calculated. The degree of influence of each factor on the value of the integrated coefficient of Credit risk assessment is analyzed. Banking management measures have been developed to improve the results of credit risk management.

Keywords: credit risks, management methods, integrated indicator, risk assessment model of the bank 's loan portfolio. 